\title{
Kimberley marine biota. History and environment
}

\author{
Barry Wilson
}

Research Associate, Department of Aquatic Zoology, Western Australian Museum, Locked Bag 49, Welshpool DC, Western Australia 6986, Australia.

Email: murexpecten@bigpond.com

\begin{abstract}
The remote tropical Kimberley region of Western Australia is introduced, its physical marine environment, habitats and classification into bioregions are described, and its marine science history is summarised. An introduction to the ongoing Western Australian Museum marine biological survey program and its objectives are also provided. The geology, metocean conditions and climate of the region are summarised. A primary division of the Kimberley coastline is noted with a northern section dominated by Proterozoic meta-sedimentary and igneous rocks (Kimberley and Bonaparte Gulf Bioregions) and a southern section dominated by Mesozoic and Cainozoic sedimentary rocks (King Sound and Canning Bioregions). In the former section inner shelf seabed sediments overlying the inundated Yampi Plateau are principally of terrestrial origin while in the Canning Bioregion they are principally marine carbonates. On the middle and outer shelf (Oceanic Shoals and North West Shelf Bioregions) sediments are primarily marine carbonates. Along the shelf margin the water is clear and oligotrophic and subject to the Indonesian Through Flow current that originates in the western Pacific. The coastal zone is macrotidal, currents are predominantly tide driven and the coastal water is turbid and probably nutrient rich. These environmental differences and the different connectivity regimes account for distinctive offshore and coastal reef communities.
\end{abstract}

KEYWORDS: marine flora, marine fauna, habitats, geology, ocean currents, climate, species distributions, biogeographic affinities, IMCRA Bioregions, science history

\section{INTRODUCTION}

The Kimberley is the northernmost part of Western Australia (Figure 1). It is sparsely populated and access to much of its $1000 \mathrm{~km}$ coastline is difficult. Partly because of this inaccessibility and the remoteness of the region, the marine environment and biota of Kimberley coastal waters and the adjacent continental shelf are less well known than more southerly Western Australian marine bioregions. This paper introduces an ongoing Western Australian Museum (WAM) survey of the Kimberley marine environment and its biota. The survey seeks to provide authoritative taxonomic, ecological and biogeographic information that will support multidisciplinary marine research and sound science based management programs in the region.

Much of the Kimberley coast has been placed on the National Heritage List and Land Title has been granted to Traditional Owners over extensive areas of coastal lands. Aboriginal communities in the region have undertaken long term management over traditional lands in their care under the Healthy Country program. Large areas of the coastal marine environment have been reserved or are proposed for reservation as marine conservation areas. In order to meet the requirement for a strong knowledge base to support these regional environmental management programs, the Commonwealth and Western Australian governments have initiated a multidisciplinary marine science program in the Kimberley, facilitated by the Western Australian Marine Science Institution. Prior to this initiative, the WAM Kimberley Woodside Collection Project began in 2008.

Establishing the composition, habitats and geographic distributions of Western Australian marine fauna is a principal objective of the ongoing WAM natural science program, derived from the institution's statutory functions. In the Kimberley, information of this kind has become especially important for three reasons: discovery of extensive hydrocarbon resources on the continental shelf in the adjacent Browse and Bonaparte Basins, rapid 


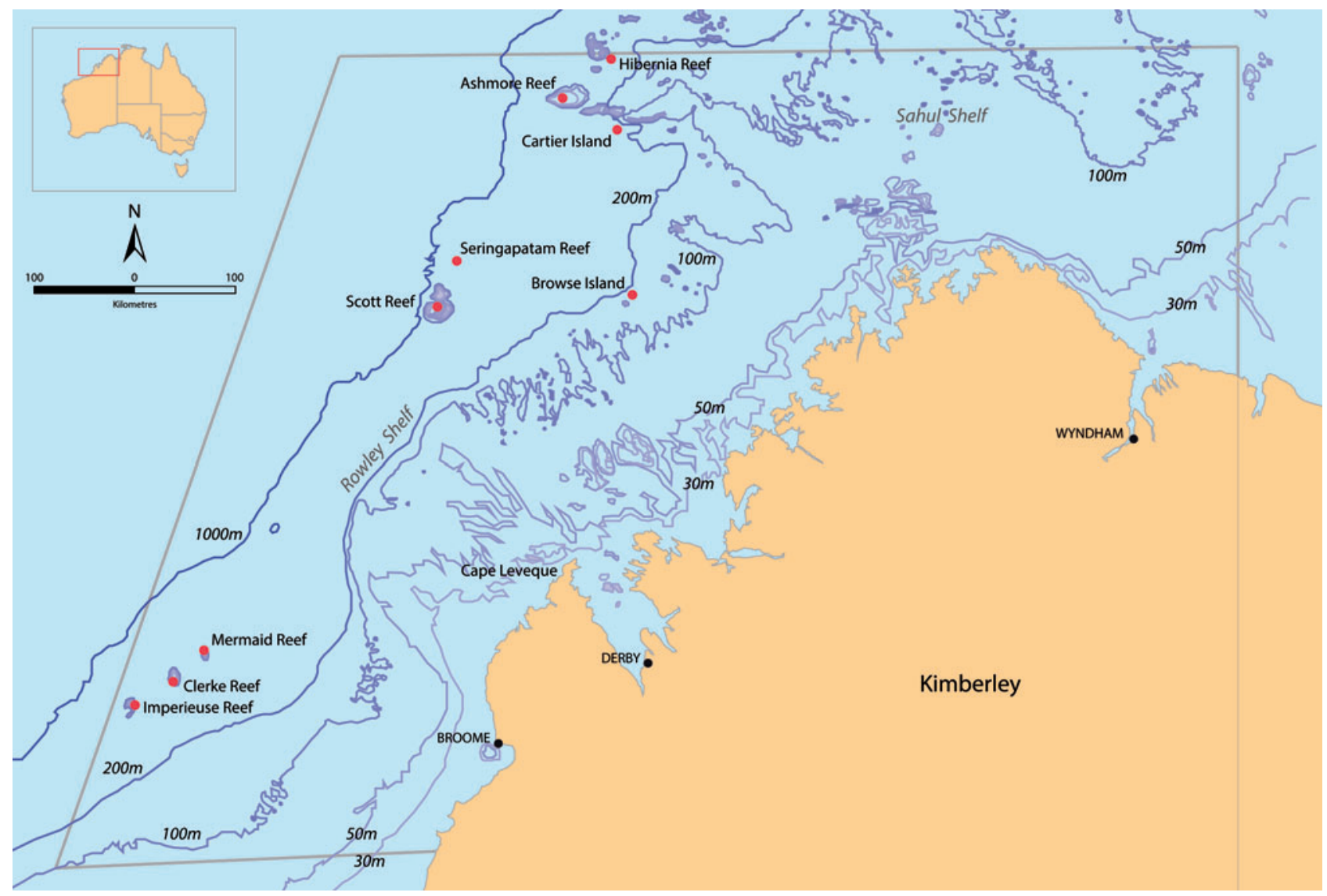

FIGURE 1

The designated Project Area (outlined in grey) depicting the complex bathymetry of the middle and inner continental shelf, and the oceanic coral atolls and platform reefs (red dots) of the shelf margin and slope.

growth of the tourism industry, and recognition of the region's very high cultural and environmental values. WAM has a dual role in this process in regard to marine fauna. The Western Australian Herbarium has complementary functions in regard to marine plants. These institutions provide taxonomic expertise that develops an inventory of species arranged according to their classification, and over time, build archives of specimens and associated information. Ultimately, taxonomically structured, soundly provenanced archival records of this kind become a vital resource for environmental studies in a rapidly changing world.

The present WAM Kimberley Woodside Collection Project, in collaboration with the Western Australian Herbarium and partner museums (Queensland Museum, Australian Museum, Museum of Victoria and Museum and Art Gallery of the Northern Territory), has three stages. The first is a collation of existing information about species of the inshore and offshore Kimberley together with their habitats and geographic distributions, drawn from the archival collections of the above agencies. A large proportion of these specimen based taxonomic records derive from the specimens and their labels, and from published and unpublished field reports of surveys carried out over the past few decades. This historical record of past survey and taxonomic work will be followed by a series of papers from recent and ongoing field surveys in the Kimberley. Details of the collection and survey stations of these expeditions will be given in a later paper. These papers dealing with archival and recent survey data establish baseline knowledge of the marine fauna and associated habitats of rocky shores and coral reefs of the region. They form the core of a comprehensive inventory of the marine flora and fauna of northern Western Australia. This introductory paper provides a summary of background information on the marine environment and the history of scientific exploration in the region to assist the understanding of species and habitat distribution patterns discussed in this series of publications. 


\section{GENERAL ASPECTS OF KIMBERLEY MARINE BIOGEOGRAPHY}

The evolutionary origins of the Kimberley biota are in the Indo-West Pacific biogeographic realm and the majority of species are widespread in the tropical Indian and Western Pacific Oceans (Wilson and Gillett 1971; Wilson and Allen 1987; Wells and Allen 2005; Wilson 2013). However, there are conspicuous differences between the assemblages of species found in coastal and offshore habitats of the region (Marsh and Marshall 1983; Wilson 1985; Wells 1990; Wilson 2013). The offshore reefs of the shelf margin carry assemblages of species that are found on oceanic reefs throughout much of the Indo-West Pacific realm with little endemic element. The majority of the Kimberley coastal marine plants and animals are also widely distributed throughout the realm, but there is a significant number of endemic species giving the coastal bioregions a distinctive character.

The differences between the offshore and coastal faunas are attributed to different environmental conditions and connectivity regimes (Wilson 2013). The offshore coral reefs along the shelf margin off the Kimberley coast lie in clear, nutrient poor, oceanic conditions directly in the path of a flow of tropical water that originates in the Western Pacific (see Figure 2). Their reef communities maintain direct pelagic connectivity with the immensely species rich bioregions of eastern Indonesia, though probably intermittently on a geological time scale. In contrast, the communities of inner shelf and coastal habitats of the Kimberley live in relatively turbid, macrotidal, nutrient rich conditions that do not lie directly in the path of the oceanic currents that flow along the shelf margin. Their connectivity regimes appear to be controlled instead by local currents driven by seasonal wind and tidal flows. There are also conspicuous differences in benthic habitats across the $200 \mathrm{~km}$ wide continental shelf from the shore and coastal waters to the shelf edge, differences that relate to substrate type. On the outer shelf and much of the middle shelf, the seafloor is sandy or muddy with low relief while on the inner shelf, at least in the northern Kimberley, hard rock pavements and rocky outcrops of high relief are often present.

Nor are the marine biota of the Kimberley coast uniform throughout its length, largely due to differences in climate, geology and the nature of seafloor sediments. There is a climatic transition along the coast from north to south. There is also a distinct change in the geology and coastal landscapes at Cape Leveque, near its centre. As a consequence of these transitions in the coastal environment, there are profound changes in the nature of inner shelf and shoreline habitats and benthic communities with their assemblages of species varying accordingly.
These cross shelf and along shelf differences of marine habitat are outcomes of geological and sedimentary history and the consequences of sea level change during the Quaternary period as well as contemporary metocean conditions. Considered together they provide a basis for a classification of the Kimberley marine environment into diverse bioregions, each characterised by distinctive habitats and biota.

\section{THE PHYSICAL ENVIRONMENT}

\section{Terrestrial climate}

Climatically, the Kimberley coast spans a transition from high seasonal rainfall in the north with many large rivers and estuaries, to arid lands in the south where rivers and estuarine habitats are lacking. The climate may be described as 'dry monsoonal' or 'tropical savannah' with distinct summer 'wet' (November to March) and winter 'dry' (May to September) seasons (Slayter 1960; Beard 1967; Jennings 1975; McKenzie 1991). At the Mitchell Plateau meteorological station the summer maximum temperatures average about $33^{\circ} \mathrm{C}$ while the minimum range is $21-24^{\circ} \mathrm{C}$. At Broome monthly average maximum temperature ranges from $34^{\circ} \mathrm{C}$ (March to April) $-27.5^{\circ} \mathrm{C}$ (July).

Heaviest rainfall occurs in the summer months, mostly associated with tropical cyclonic storms. From the relatively wet north Kimberley there is a progressive change to semi-arid and arid conditions in the south. Annual rainfall averages more than $1,400 \mathrm{~mm}$ on the Mitchell Plateau in the north Kimberley and less than $600 \mathrm{~mm}$ south of Broome.

The climate is influenced by the low pressure zone of the monsoonal belt during the wet season with north-westerly, rain bearing winds. South-easterly trade winds prevail in the dry season. During the transitional months between the monsoon and trade wind seasons, winds are light and unsteady.

Cyclonic storms are a feature of the Kimberley between December and April, typically moving south-west across the Arafura and Timor Seas, with many turning to cross the coast. They may be destructive to shallow marine environments and storm surges are common.

\section{Marine environment}

Offshore at Scott Reef surface sea temperature ranges from an August average of $24.5-29.0^{\circ} \mathrm{C}$ in January to April. At Ashmore Reef surface sea temperature averages $29.4^{\circ} \mathrm{C}$, ranging from 25.4$30.2^{\circ} \mathrm{C}$, but reaching as high as $38.4^{\circ} \mathrm{C}$ in the lagoon (Glenn 2005). Tidal range is of the order of $4.5 \mathrm{~m}$ at the offshore shelf edge reefs.

In Kimberley coastal waters the range in surface sea temperature is a little greater. CSIRO records monthly mean sea temperatures in Roebuck Bay 
ranging from $21.5^{\circ} \mathrm{C}$ (July) to $31^{\circ} \mathrm{C}$ (January). This is a low energy, semidiurnal, macrotidal region; the tidal range is extreme, tidal currents are pronounced and the coastal waters are turbid. On the mainland coast the spring tide range is over $11 \mathrm{~m}$ in King Sound, but less on the north Kimberley and south Canning coasts.

Surface currents along the shelf margin, from the Sahul Shelf to the Rowley Shoals and beyond, are dominated by oligotrophic oceanic water that originates in the Western Pacific (Figure 2). This transfer of water from the Western Pacific Ocean to the north-eastern Indian Ocean is driven by steric pressure. It passes through the passages between West Irian and the eastern islands of Indonesia and is known as the Indonesian Through Flow (ITF). Part of it flows into the Arafura and Timor Seas and thence south-west along the margin of the North West Shelf as a seasonal surface flow called the Holloway Current, driven by the south-easterly trade winds (D'Adamo et al. 2009). It flows most strongly, but frequently reversing, between March and September, then weakens. The ITF and the Holloway Current profoundly influence the biogeography of the North West Shelf providing a mechanism for pelagic connectivity with the immensely species rich centre of marine biodiversity located in the central Indo-West Pacific region.

On the continental shelf off the Kimberley coast, currents are primarily along shore, wind driven flows with seasonal reversal associated with the change from winter south-easterly trade winds to westerly summer monsoon. In winter months there is said to be a south-westerly flow from the

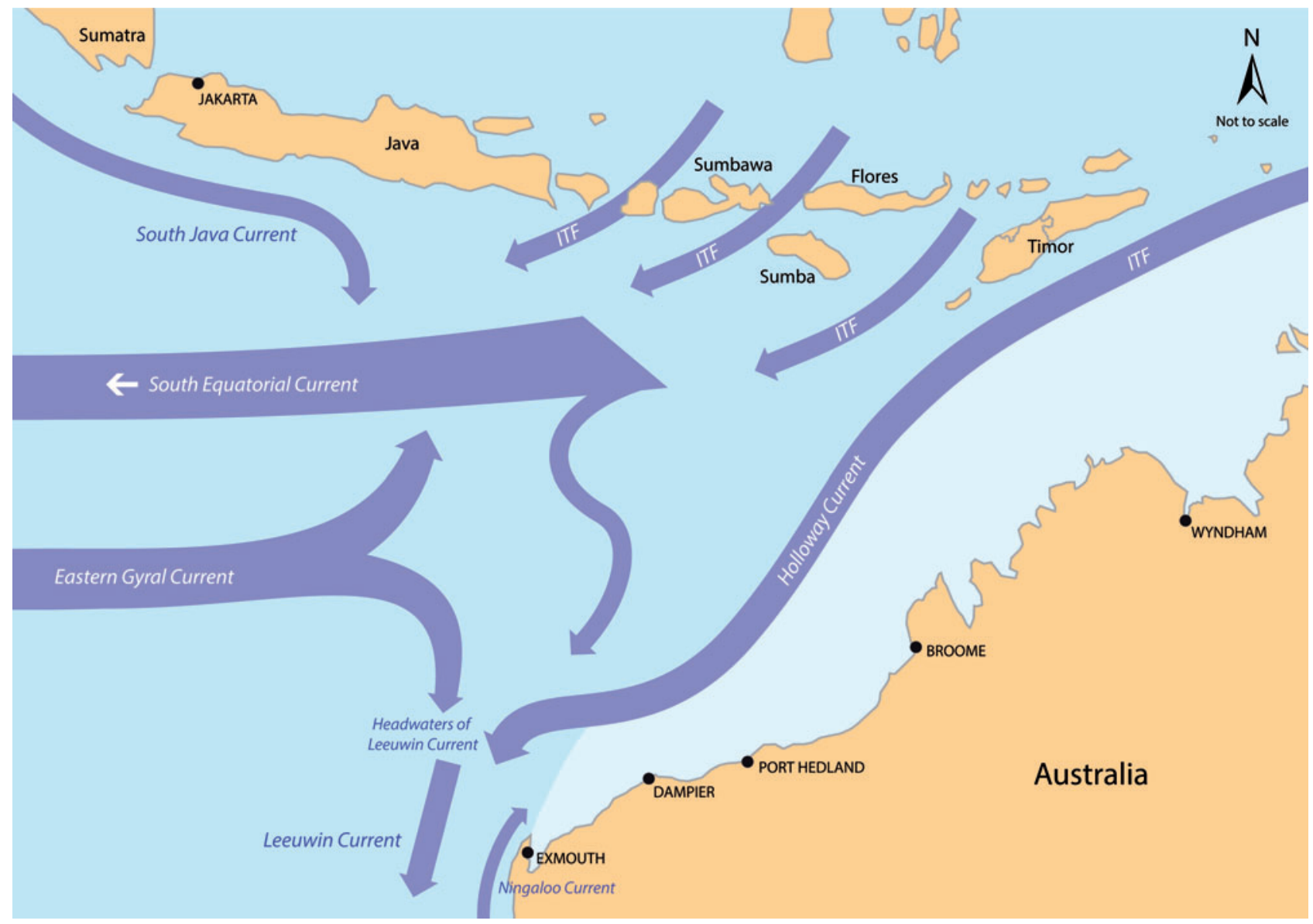
current affecting the Kimberley region is the seasonal, largely wind-driven Holloway Current that flows south-west along the shelf margin from May to September. It is derived from the Indonesian Through Flow (ITF), a flow of Pacific water that passes between the islands of the Indonesian Archipelago into the Arafura and Timor Seas. The Holloway Current affects mainly the outer shelf and offshore reefs of the shelf margin. The extent of its mixing with inshore waters of the Kimberley coast is a key issue for further study. 
Joseph Bonaparte Gulf along the Kimberley coast (Glenn 2005). However, in the nearshore zone these regional wind driven currents are frequently over ridden by tidal currents, especially during spring tides when tidal range is extreme. At those times, tide driven local currents may be multidirectional, their direction and velocity greatly influenced by seabed topography, especially in the northern part of the Kimberley coast where the seafloor has high and irregular relief.

The extent to which the Holloway Current water mixes with the coastal water of the middle and inner shelf and influences the benthic shelf and shore biota of the Kimberley coast is uncertain. This is a critically important matter that needs investigation.

\section{GEOLOGICAL AND GEOMORPHIC SETTING}

The Kimberley coast embraces five different geological regimes; one orogen and four basins whose characteristics determine the basic features of shore and shelf habitats of the region (Wilson 2013, figure 2.2). There is a profound change in the geology and geomorphology at the centre of the Kimberley coastline. In the north the modern coast is formed along the margins of the Precambrian King Leopold Orogen and Kimberley Basin. Rocky shores predominate and the coastline is complex with drowned valleys forming gulfs and inlets, and more than 2,550 rocky islands resulting in a dramatic coastal landscape of extraordinary scenic quality. In contrast, the coastline from Cape Leveque southward overlies the sedimentary Canning Basin, and the shores of the south-western Kimberley are predominantly sandy with low relief, long beaches and occasional headlands of Mesozoic and Quaternary rocks. The habitat forming characteristics of the coastal geology carry over onto the inner continental shelf where they are a primary factor in determining the nature of benthic shelf habitats.

\section{King Leopold Orogen}

Geologically the King Leopold Orogen is a complex band of Proterozoic metamorphic and igneous rocks bordering the southern margins of the Kimberley Basin and incorporating its marginal sedimentary rocks. It has been subjected to intense tectonic activity (Griffin and Grey 1990a). The western end of the orogen is intensely folded (Yampi Fold Belt) and forms the rocky ria coast of the Yampi Peninsula and the adjacent islands of the Buccaneer Archipelago - one of the most dramatic land-seascapes of the Australian coastline.

While the King Leopold Orogen, including the Buccaneer Archipelago, differs in tectonic history and to some extent in geological and geomorphic characteristics from the north-western coast of the
Kimberley Basin and the Bonaparte Archipelago, in terms of habitats there is enough in common for them to be considered together as sections within a single bioregion.

\section{Kimberley Basin}

Geologically the Kimberley Basin comprises a succession of Proterozoic metamorphosed sedimentary rocks with some volcanic and intrusive igneous rocks, which are overlain by areas of Cainozoic laterite deposits, all outcropping to form the rocky shores that characterise the coastline (Griffin and Grey 1990b; Tyler et al. 2012). The Palaeoproterozoic sedimentary rocks within the Kimberley and Speewah Basins generally were deposited in fluvial to shallow marine environments 1835-1790 Ma. Today the Kimberley Basin is mainly exposed terrestrially, but it has a narrow submarine component around its north-western and north-eastern margins where it is now inundated by the sea. By far the most common shoreline rocks are the strongly jointed and more or less flat bedded Warton and King Leopold Sandstones of the early Proterozoic Kimberley Group. There are shallow deposits of Quaternary alluvial and colluvial sediments along the coast, but exposures (above high tide level) of Pleistocene coastal and marine limestone deposits are conspicuously absent.

The contemporary land surface of the Kimberley Basin is a dissected plateau, primarily an ancient subaerial erosion surface developed on flat lying rocks (Jutson 1934; Wright 1964; Young 1992). The north-western margin is deeply dissected by terrestrial erosion with high hills and deep river canyons. As a consequence of subsidence and Holocene sea level rise, this complex escarpment was inundated by the sea, forming a ria coastline with high relief, major gulfs and inlets and many nearshore rocky islands. Rocky habitats predominate on the shores although extensive muddy shores and mangrove forests occur in the estuarine gulfs and sheltered bays. Fringing and nearshore patch and platform coral reefs, comprising Holocene coral growth are prevalent in the coastal zone of the north-western Kimberley.

The submerged north-western margin of the Kimberley Basin forms a coastal terrace of the inner continental shelf known as the Yampi Shelf, its seaward edge bounded by a fault that marks the boundary of the offshore sedimentary Browse Basin. The seabed of the Yampi Shelf, to a depth of around $50 \mathrm{~m}$, is an inundated terrestrial land surface with extremely varied topography representing its ancient terrestrial erosional history. Exposed rock pavement is commonplace and there are banks of contemporary marine sediment ranging from mud to coarse gravel. 
The reef at Adele Island, and the nearby Churchill, Mavis, Albert and Beagle Reefs, are platform reefs located on the outer margin of the Kimberley Basin. These reefs probably have Quaternary origins with marine limestone overlying a shallow base of Kimberley Proterozoic rocks. Unlike the reef at Browse Island in the Browse Basin (see below) these reefs have elongated outlines aligned with underlying geological structure in the Proterozoic basement.

The north-eastern margin of the Kimberley Basin forming the south-eastern shore of Joseph Bonaparte Gulf was also inundated by the sea, but never dissected by previous terrestrial erosion as much as the western margin, so that coastline is relatively straight and featureless.

\section{Canning Basin}

The Canning Basin (Williams and Soufoulis 1971; Horstman and Purcell 1988; Middleton 1990), containing Ordovician to Holocene sedimentary rocks, is very large and a third of its exposed area lies offshore. The inner shelf and onshore parts abut the south-western margin of the King Leopold Orogen. At Cape Leveque, on the tip of the Dampier Peninsula, the boundary between the Canning Basin and the King Leopold Orogen crosses the coast, marking an abrupt change of coastal geology from Proterozoic metasedimentary, metamorphic and igneous rocks to CretaceousCainozoic sedimentary rocks, with a corresponding abrupt change of coastal geomorphology and coastal marine habitats.

Onshore, the Canning Basin includes the Dampier Peninsula and the arid shrublands south of Broome. On the Dampier Peninsula the surface rocks are Cretaceous (mainly sandstones) overlain in places by Cainozoic alluvial and aeolian sands. The coastline comprises mainly beaches backed by aeolian dunes, but there are some rocky headlands where the Cretaceous sandstones outcrop and several stretches of rocky shore with limestone rock platforms, said to be part of the Quaternary Bossut Formation (e.g. at Packer Island and North Head). This west-facing stretch of the Kimberley coast and the adjacent coastal waters comprises the Canning Bioregion in the Interim Marine and Coastal Regionalisation of Australia (IMCRA) classification. King Sound is a large estuarine gulf developed over the onshore part of the Canning Basin, between the Dampier Peninsula and the margin of the King Leopold Orogen. The geology of the hinterland at the head of King Sound is dominated by Triassic and Jurassic sedimentary rocks, but these do not form shores because they are fronted by wide, complexly stratified, Quaternary mudflats and alluvial plains (Semeniuk 1980, 1981a, 1981b, 1982, 2011).

In this southern part of the Project Area, south of
Cape Leveque, the entire continental shelf is gently inclined and of rather uniform profile over seabed sediments of the Canning Basin.

The Rowley Shelf Platform is a wide marginal terrace at depths of 550-600 $\mathrm{m}$ on the continental slope in the offshore part of the Canning Basin, with biogenic reef growth on a series of topographic highs, probably initiated in the middle Tertiary (Jones 1973). Reef growth of three of these has kept pace with subsidence and today these biogenic structures form the shelf edge atolls known as the Rowley Shoals, which are vigorous modern coral reefs with central lagoons and steep to vertical perimeter walls. There is a fourth structure of similar origin a little further south that remains today as a submerged bank that may be an example of a 'failed reef' where coral growth has been overcome by sea level rise and subsidence.

\section{Browse Basin}

The Lower Permian to Quaternary Browse Basin is located entirely offshore and has no terrestrial component except for several sand islands. Its northern and southern margins merge imperceptibly with the Bonaparte and Canning Basins on either side while its inner margin onlaps the submerged parts of the Kimberley Basin. On the seaward side the Browse Basin extends to the continental margin and includes the subsiding portion of the continental slope known as the Scott Plateau. The basin is rich in hydrocarbon resources. Willis (1988) and Elliott (1990) have described the geology in detail.

The shelf margin of the Browse Basin, comprising the Oceanic Shoals Bioregion, is characterised by clear, oligotrophic oceanic water and vigorous growth of modern coral reefs including atolls, platform reefs and submerged banks. Seringapatam Reef and Scott Reef (North and South) are annular shelf-slope atolls that originated on topographic highs on the Scott Plateau, probably in the Miocene. They arise precipitously from depths of 500-800 m and have deep lagoons and outer perimeter walls that are vertical in the upper part with steep scree slopes at the base. Browse Island, rising from depths around $150 \mathrm{~m}$ on the edge of the continental shelf, is also a biohermic structure, but has the circular form of a typical shelf planar platform reef with a central sand island and no lagoon.

Like the Rowley Shoals, biogenic growth of the coral reefs in the Browse Basin has kept pace with subsidence (Collins et al. 2011), but on the outer continental shelf near Browse Island there are several non-emergent banks (e.g. Echuca and Heywood Shoals) that are probably of similar origin to Browse Island. These may be failed reefs whose coral growth has not kept pace with subsidence and sea level rise. 


\section{Bonaparte Basin}

The Project Area overlies the western part of the Bonaparte Basin, which contains Cambrian to Cainozoic sedimentary rocks and is the most northerly of the sedimentary basins of the North West Shelf. The northern Bonaparte Basin is primarily offshore, but there are minor terrestrial components at the head of Bonaparte Gulf and several offshore Quaternary sand islands. It underlies the northern portion of the North West Shelf known as the Sahul Shelf and holds rich hydrocarbon resources. Gunn (1988), Mory (1990) and Glenn (2004) have summarised the extensive geological literature.

The Bonaparte Basin has complex bathymetry. Its northern margin is the very steep continental slope that borders the Timor Trough and is subject to ongoing subsidence associated with subduction of the Australian shelf margin below the Eurasian Plate that commenced in the Late MiocenePliocene (O'Brien and Glenn 2005). The Ashmore and Sahul Platforms are structural highs on the outer shelf bordering the trough with a chain of emergent reefs (Ashmore and Hibernia Reefs and Cartier Island) and non-emergent banks (Sahul Banks). These structures are bioherms probably originating in the Pliocene. The reefs in the west have kept pace with subsidence and sea level rise and are dominated by modern coral growth. The submerged banks along the margin of the trough may be failed reefs, dominated today by calcareous algal growth (Lavering 1993; Heyward et al. 1997) although failure of ongoing coral growth could have ecological causes other than sea level change (Wilson 2013). O'Brien and Woods (1995) suggested that development of seafloor mounds formed by hydrocarbon leakage may have had a causal role in the origin of the modern reef structures on the Sahul Shelf.

At the centre of the Sahul Shelf there is a deep depression known as the Bonaparte Depression. At the time of the Last Glacial Maximum when sea level was about $125 \mathrm{~m}$ lower than at present this depression is thought to have been a wide inland estuarine gulf draining to the north through the Malita Shelf Valley (Lavering 1993; Yokoyama et al. 2000; Glenn 2004), and is now a conspicuous feature of the seabed. There is also a series of incised palaeo-channels draining to the west, including the major Penguin Deep.

\section{Seabed sediments}

The outer continental shelf off the Kimberley coast is a plain with a near level surface dominated by biogenic carbonate sediments (Carrigy and Fairbridge 1954; James et al. 2004). It is gently inclined with a slope of less than one degree, and is rather featureless although there are areas of linear mega-ripples and large sand waves, indicating strong cross shelf bottom currents.

The middle shelf is also gently sloping, but there are large and deep cross shelf channels, thought to have been major late Pleistocene river beds in incised canyons. Teichert and Fairbridge (1948) and Fairbridge (1953) described seabed canyons across the middle shelf at many locations off the Kimberley coast, such as those separating Adele Island, Churchill and Beagle Reefs. Some of these extend beyond the limits of eustatic low sea levels and were interpreted by those authors as evidence of regional subsidence of the continental shelf adjacent to the Kimberley coast.

Changing sea levels during the Quaternary also left drowned terraces and steps along the outer and middle shelves. The most prominent of these lies at around the $120 \mathrm{~m}$ bathymetric contour and appears to represent a still-stand period during the Last Glacial Maximum (Jones 1973). That ridge has a seaward facing rocky escarpment bearing a dense epifauna with associated demersal fishes and is a target zone for the Kimberley trap fishery. There are striking differences between the sediments and seafloor topography of the inner shelf areas adjacent to the Kimberley and Canning coasts. Off the Canning coast south of Cape Leveque, where the shelf is formed over the sedimentary Canning Basin, an inclined sedimentary plain of low relief extends to the shore and the sediments are primarily biogenic carbonate sands. However, north of Cape Leveque the coastal surface sediments are primarily terrigenous (Carrigy and Fairbridge 1954; Baker et al. 2008). There the nearshore seabed is formed over the margin of the Proterozoic Kimberley Basin and the bathymetry is extremely irregular, inheriting its topographic features from its terrestrial erosional history prior to inundation. There are valleys with palaeo-drainage channels and high relief structures such as Montgomery Reef, interpreted as a drowned, flat-topped mesa of Proterozoic rocks with a veneer of Quaternary biogenic limestone (Wilson and Blake 2011). There are also contemporary marine topographic features on the seabed that include tidal scour channels and mounds of gravel built by interacting tidal currents.

In the vicinity of Montgomery Reef, rock pavements have little sediment overlay, presumably because of extreme tidal scouring (personal communication A. Heyward, Australian Institute of Marine Science), but where sediment exists it consists mainly of terrigenous muds, sands and gravels. The large Fitzroy River in flood delivers massive amounts of fine terrigenous sediment via King Sound to the nearshore shelf. Further north there are many other rivers, draining the 
high rainfall coastal lands of the Kimberley Basin, presumably also delivering terrigenous sediments.

The change of inner shelf substrate from predominantly carbonate sands in the nearshore Canning Bioregion to mainly terrigenous muds and gravels in the Kimberley Bioregion represents a fundamental change in benthic habitats that may be partially responsible for the biogeographic differences observed between these two bioregions.

\section{BIOREGIONS OF THE KIMBERLEY PROJECT AREA}

Reflecting the varied along shelf and cross shelf physical and biotic characteristics of the Kimberley marine environment, a set of distinctive bioregions have been recognised, known as the Interim Marine and Coastal Regionalisation of Australia (IMCRA) Bioregions (Commonwealth of Australia 2006) (Figure 3). For descriptive and planning purposes it is useful to build physical and biological information around the framework that this biogeographic classification provides.

The IMCRA Bioregions comprise two different arrangements. One system, based on demersal fish data, applies to shelf habitats, mainly in
Commonwealth waters, and the units are referred to as the Provincial Bioregions. The other applies to shelf and coastal habitats and the units are referred to as Meso-scale Bioregions.

\section{CAMBRIDGE-BONAPARTE BIOREGION}

This small bioregion is located nearshore at the head of Joseph Bonaparte Gulf, its seabed comprising terrestrial muds. The shore has very wide intertidal mudflats backed by a mangrove fringe and extensive supra-littoral mudflats and two major estuarine systems - Cambridge Gulf (Ord, Pentecost and Durack Rivers) and a complex of three estuaries (Keep, Victoria and Fitzmaurice Rivers). The mangroves of the bioregion have been described (Semeniuk 1993), but otherwise there is little information on the habitats and biota.

\section{BONAPARTE GULF BIOREGION}

Joseph Bonaparte Gulf occupies the inner shelf area straddling the Western Australian-Northern Territory border. Its mainly sand and gravel seafloor sediments support a moderately diverse benthic fauna. This eastern side of the Kimberley

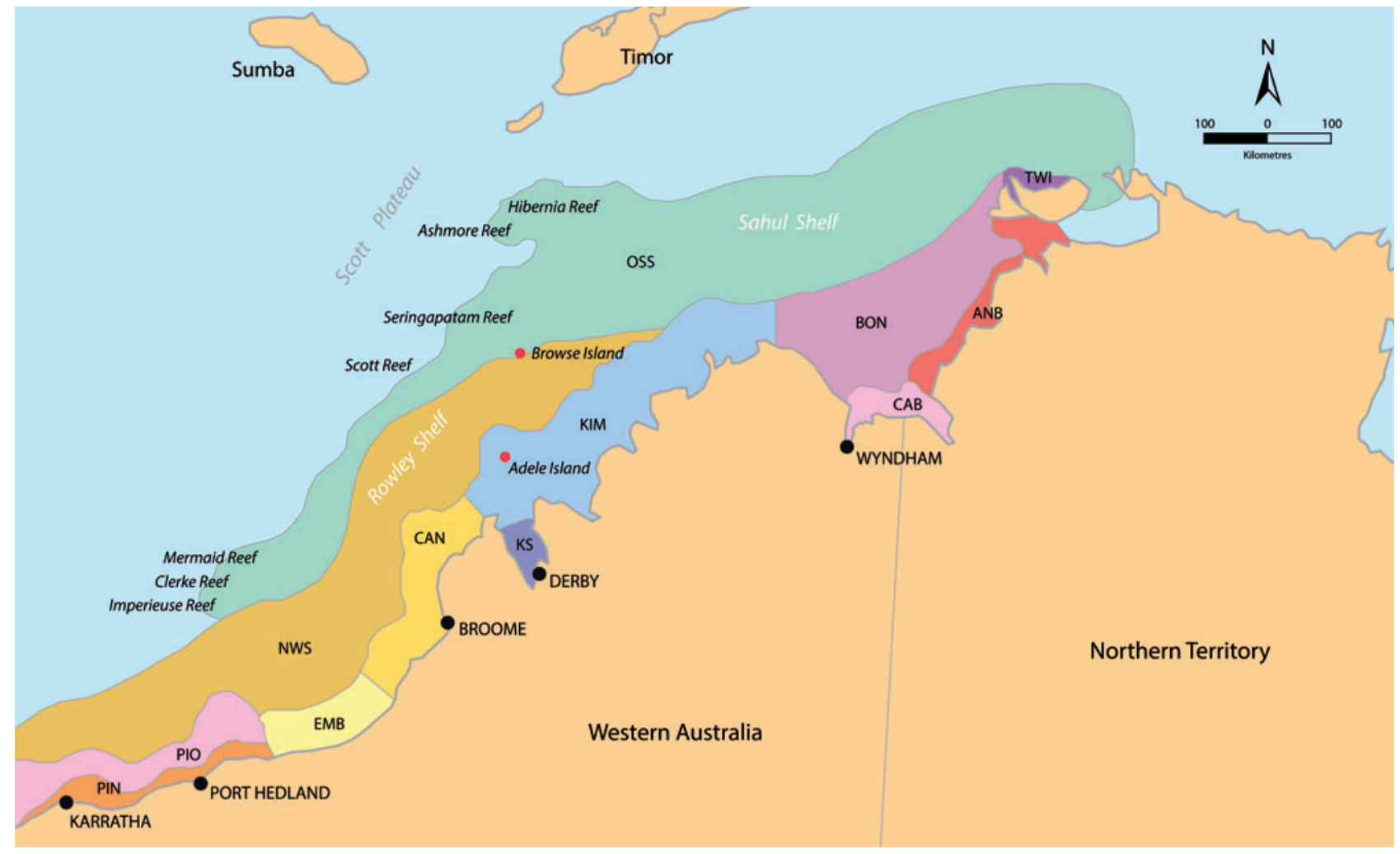


coast, from Cape Londonderry to Cambridge Gulf, is rather straight without the ria character of the north-western coast. There are several small nearshore islands and several rivers but no major estuaries. Mangroves form a narrow fringe. Only brief reports from exploratory collecting sites (Walker et al. 1996) provide information on the coastal biota. A study by the Australian Institute of Marine Science (AIMS) and Geoscience Australia (Przeslawski et al. 2011) of the benthic environment of the eastern part of Joseph Bonaparte Gulf lying outside the Project Area probably represents benthic habitats and biota of the whole gulf.

\section{KIMBERLEY BIOREGION}

The Kimberley Bioregion covers coastal waters of the north-western Kimberley coast from Cape Londonderry to Cape Leveque. This is a macrotidal area (spring tidal range over $11 \mathrm{~m}$ in the south) and its coastal waters are subject to extreme tidal currents and high turbidity. The sediments of the inner shelf are primarily terrestrial muds and gravels, but there are extensive areas of rocky seafloor. The complex topography of the dissected Kimberley plateau continues far beyond the present coastline, and the seabed of the inner shelf, to depths of $50 \mathrm{~m}$, is highly irregular.

The inundated ria coast forming the northwestern margin of the Kimberley has high relief, rocky shores and cliffed headlands. There are many coastal islands, including the Bonaparte and Buccaneer Archipelagos, the islands being high points of the pre-inundation landscape. Large gulfs and inlets receiving discharge of major rivers are commonly estuarine and support well developed mangrove habitats with a relatively high diversity of mangroves, 15 species according to Cresswell and Semeniuk (2011). Beaches between headlands are generally steep, short and lunate. Intertidal sand flat habitats are uncommon, but there is extensive development of intertidal rock platforms and fringing coral reefs throughout the bioregion

The biota of this bioregion are still being surveyed, but there is now considerable information available, mainly as a result of a series of WAM and AIMS surveys since 1989, including the surveys described in this series of papers.

\section{KING SOUND BIOREGION}

King Sound is ecologically complex and not a coherent bioregion. The lower part of the sound is estuarine, receiving seasonal discharge from the Fitzroy, Meda and May Rivers, and characterised by vast intertidal mudflats, mud banks and fringing mangals. However, in the north, on either side of the entrance, marine habitats are typically coastal marine in character. On the north-eastern side of the sound, south to about Point Osborne, the shores are rocky (Precambrian) and the area belongs to the Kimberley Bioregion. On the north-western side, south to about Cunningham Point, the shore is like that of the Canning Bioregion with long sandy beaches and rocky headlands (Mesozoic). Semeniuk (1980, 1981a, 1981b) has described the geomorphology and sedimentation of King Sound, but the biota remain little studied, particularly that of the estuarine habitats in the south.

\section{CANNING BIOREGION}

The Canning Bioregion takes in the southern $500 \mathrm{~km}$ of semi-arid to arid coast of the Project Area between Cape Leveque and Cape Missiessy. It is a macrotidal region (tidal range up to $9 \mathrm{~m}$ ) and the coast is tide dominated.

The inner shelf of this bioregion is gently inclined and the seafloor has little relief except for some tidal scour channels. Long stretches of beach are interrupted by occasional rocky headlands (mainly Mesozoic sandstone, siltstone and shale) and there are some Quaternary limestone intertidal rock platforms. Wide intertidal sand and mudflat habitats are a conspicuous feature of the bioregion. There are no coral reefs (in the sense of reef communities building coral-algal framework) except perhaps for fringing reefs surrounding the Lacepede Islands in the north, off the coast of the Dampier Peninsula. There are no rivers or estuaries although there are embayments behind limestone and dune barriers. Seepage has a major effect on the development of mangrove habitats in the embayments.

Though little studied to date, this bioregion is one of high biodiversity, especially in benthic soft substrate habitats (Wilson 2013). In areas of exposed rocky seabed there are rich epifaunal filter feeding communities of invertebrates, including many corals (although they are not reef building). Benthic filter feeding habitats of this kind are the pearling grounds for which this bioregion is famous. Rocky shore and mangrove communities are moderately well developed, although the mangroves are less species rich than those of the wetter Kimberley Bioregion.

\section{NORTH WEST SHELF BIOREGION}

This bioregion occupies the middle part of the Rowley Shelf, off the coasts of the Kimberley and Pilbara regions. Its waters are clear and wave energy is moderate (except during extreme conditions prevailing in cyclonic storms). Its outer margin is thought to be affected by the flow (southerly, though seasonally reversing) of oceanic, oligotrophic water of the Holloway Current. Although there are some banks over topographic 
highs, there are no emergent reefs or islands in this bioregion and the seafloor is gently inclined to the shelf edge with little relief.

In the north, the North West Shelf Bioregion overlies the Browse Basin, adjacent to the Kimberley Bioregion and in the south it overlies the offshore Canning Basin, adjacent to the Canning Bioregion. Although little studied, it is believed the benthic biota of the North West Shelf Bioregion is diverse. Soft biogenic carbonate sediments and infaunal communities dominate the seabed, but there are also extensive areas of exposed rock pavement and some rocky ridges representing old coastlines where there are dense and diverse epifaunal, filter feeding communities.

\section{OCEANIC SHOALS BIOREGION}

This bioregion overlies the shelf edge and continental slope of the North West Shelf, extending from the Rowley Shoals to the Sahul Banks bordering the Timor Trough. It is characterised by outer shelf and deep sea benthic habitats and a series of emergent coral reefs and non-emergent banks. The coral reefs include slope atolls arising from marginal terraces on the continental slope (Seringapatam and Scott Reefs and the Rowley Shoals) and the reefs (Hibernia and Ashmore Reefs and Cartier and Browse Islands) arising from the margin of the outer shelf. All these ancient biohermic structures have rich coral reef communities typical of oceanic reefs of the Western Pacific and Indian Oceans. In the north-eastern part of the Project Area, the non-emergent Sahul Banks are also bioherms, but today these are dominated by calcareous algal communities (mainly Halimeda) rather than coral reef communities, although there are extensive areas of benthic corals.

The reefs and banks are surrounded by gently sloping plains of soft sediments (though with some shelf edge canyons). From north to south, the bioregion overlies the Bonaparte, Browse and Canning sedimentary basins. The surface sediments are primarily biogenic carbonates with a superficial layer of pelagic sediment.

Throughout its length this bioregion lies directly in the path of the ITF and Holloway Current and its coral reefs are thought to owe their historic origin to carriage of planktotrophic larvae from the immensely species rich centre of marine biodiversity of the Central Indo-West Pacific biogeographic realm (Wilson 2013). The oceanic water characterising the bioregion is clear and oligotrophic, which together with the direct pelagic connectivity with the Central Indo-West Pacific realm, results in reef communities that are significantly different from those of the continental reef biota along the Kimberley coast.
The benthic infaunal communities, at depths below about $200 \mathrm{~m}$ on the continental slope and marginal terraces of the bioregion, comprise deep sea species, dominated by infaunal polychaetes and diverse assemblages of molluscan and crustacean detritus feeders and predators. Very little is known of this deep sea fauna. It clearly has little affinity with the benthic fauna of the adjacent shelf, although there is probably some overlap of the two along the shelf edge.

\section{THE HISTORY OF MARINE SCIENCE IN THE KIMBERLEY}

The first Europeans with scientific interests known to have visited the Kimberley coast were Abel Tasman who mapped part of the coast in 1644, and William Dampier in 1688 and 1689. Neither made any marine biological collections as far as is known. However, from observations made along the coast of what is known today as the Dampier Peninsula, Dampier postulated the existence of large rivers on the Kimberley coast, which might give access to the interior, a proposition that stimulated subsequent European interest.

\section{FRENCH AND BRITISH HYDROGRAPHIC SURVEYS IN THE 19TH CENTURY}

Scientific study of the area began with the French Baudin Expedition of 1800-1804 under the command of Nicholas Baudin (Cornell 1974). On the way to Timor, following scientific work in Shark Bay, Baudin sailed the ship Géographe along the Kimberley coast in July to August 1801, but stayed mostly offshore. He returned, accompanied by the Casuarina under the command of Louis de Freycinet, in June 1803 and made hydrographic surveys along the Kimberley coast. During these visits the Bonaparte Archipelago and many of the Kimberley islands were named. However, there is no record of the biologists aboard having gone ashore or collected any specimens.

Around the same time (July 1802 to March 1803) Englishman Matthew Flinders, commanding the Investigator with botanist Robert Brown aboard, surveyed the coasts of North Queensland, the Gulf of Carpentaria and Arnhem Land. However, the ship became unsound and the expedition returned to Port Jackson via Timor, bypassing the Kimberley coast.

Philip Parker King was commissioned by the British Admiralty to survey the Kimberley coast (1820-1821) initially on the vessel H.M.C. Mermaid, replaced later by the Bathurst. Like Baudin, King named many islands and localities along the coast. Between them they left a heritage of English and French names such as the Buccaneer and Bonaparte Archipelagos. 
King was accompanied by botanist Allan Cunningham who collected terrestrial plants for the Kew Gardens in London. Geological specimens, marine fishes and invertebrates were also collected. In the Appendices to his narrative King (1827a) lamented that the natural history collections were 'so trifling in number' and wrote, 'The very few specimens that are now offered to the world were procured as leisure and opportunity offered but many interesting and extremely curious subjects were in fact obliged to be left behind from want of room, and from our not possessing apparatus for collecting and preserving them'. Nevertheless, significant collections were made by King's party and reports on them were included in the Appendices to his narrative. These reports refer to specimens collected at many places, including some non Australian localities. Although they include descriptions of new species, unfortunately specific localities are not usually given and those from Kimberley localities are not always indicated.

John Gray, of the British Museum of Natural History, reported on a small collection of seven kinds of fish (Gray 1827a) including one he described as new, but they were not indicated as coming from the Kimberley. King's marine invertebrate collection included three species of echinoid and two pelagic coelenterates, but no localities were given and it is not clear who was the author of those short reports. One of the coelenterates, identified as Porpita gigantea Péron, was said to have been 'beautifully drawn' by Lieutenant Roe (John Septimus Roe, the expedition's assistant surveyor, who later became Western Australia's Surveyor General).

Another of the reports in Appendix B, apparently written by King, listed 20 species of coral and five sponges. Localities are not given, but in his narrative King (1827b) recorded finding three of those species of coral at low tide on a reef at the Midway Islands near the entrance to Munster Water on the Kimberley coast. These may have been among the first Australian coral specimens collected for scientific purposes, but if they exist their present location is not known.

One large report in Appendix B was on molluscs (Gray 1827c), including 111 marine species of which 24 were described as new. It is most unfortunate that specific localities were given for only a few of them. From what is known now of the distribution of mollusc species it is clear that many of King's specimens were from the temperate waters of southern and south-eastern Australia. Of the species known to be from the tropical north, most could have come from either the north-west or north-east coast. Gray noted that 25 specimens from this collection had been donated to the museum (presumably by King). The fate of the remainder, including many types, is unknown. However, catalogues of the Natural History Museum, London include a reference to specimens 'Purchased at Steven's Sale room, collection of W.R. Brown Collected by Captain P.P. King'. As was common practice in those times it appears likely that King sold some of his natural history specimens after they had been made available to scientists like Gray, with some eventually finding their way back to the Museum.

King's narrative of his Kimberley adventures makes enthralling reading. In the tradition of British naval officers of his time, he was highly literate, well educated in natural science and a competent water colour artist as well as an outstanding commander, seaman and hydrographer. For those of us who work on that extremely difficult coast today, with all our safety and communication facilities, it seems an extraordinary feat for King and his crew to have worked there for so long, in such small sailing vessels, fulfilled their mission and achieved so much, without loss of life. Philip Parker King began the study of marine natural science in the Kimberley and this series of papers follows in the tradition he established so long ago.

Following the work of King there was intense interest in the north-western Australian coast because of its proximity to Asia and the passage through the Torres Strait that provided access to the English colonies on the east coast. In 1837, the British Admiralty commissioned H.M.S. Beagle, commanded by John Clements Wickham, to refine the surveys made by Flinders and King of the channels in the Torres and Bass Straits and explore 'certain parts of the north-west coast of New Holland'. The expedition lasted for six years. In March 1841 Captain Wickham returned to England because of ill health and John Lort Stokes became Commander. The journal of the expedition was written by Stokes (1846).

In addition to the Admiralty instructions given to Wickham on the survey objectives of the expedition, the hydrographer, F. Beaufort, set out some scientific objectives that included observations on work of 'the coral insect' and the means of reef development. No doubt, this was related to the work of Charles Darwin and J.D. Dana who were both developing ideas on this matter about that time, and who published their theories soon after (Darwin 1842; Dana 1853). In his narrative (p. 331) Stokes (1846) described hearing a paper delivered to the Geological Society by his friend Darwin prior to the departure of the Beagle, on the formation of coral islands. (Stokes and Darwin had been shipmates aboard the Beagle during its famous earlier expedition around the world.) Darwin asked him to investigate some specific questions about raised coral reefs in northern Australia. In his narrative of the expedition Stokes made observations on a raised fossil reef at Cape Upstart on the Queensland coast (pp. 332-333). 
On the Kimberley coast he made frequent reference to coral reefs, for example, deep coral ledges in the vicinity of Adele Island (pp. 184-185) and extensive fringing reefs at Bathurst Island in the Buccaneer Archipelago (p. 171), but he did not discuss their mode of formation or provide any description of them.

During the explorations of the Beagle around the Australian coast many natural history specimens were collected and reports on some of them were published by zoologists from the British Museum in an appendix to Stokes' journal (Volume 1, pp. 479-521). Sir John Richardson described six species of fish collected by the expedition (pp. 484-497). Unfortunately, as was the case with the King collections, indications of which specimens were collected in the Kimberley were rarely given.

British surveys of the Kimberley coast were continued by H.M.S Penguin in 1890 and 1891. Coral collections were made by P.W. Bassett-Smith, an officer aboard the vessel, from Holothuria Bank, Baudin Island, Troughton Island and Baleine Bank off Broome. He published brief field notes about them, remarking on the peculiarity of the presence of corals in such turbid and extreme tidal conditions (Bassett-Smith 1899).

Around the same time the English biologist W. Saville-Kent visited the West Kimberley and collected corals at the Lacapede Islands, King Sound and Roebuck Bay. The Bassett-Smith and Saville-Kent corals are preserved in the collections of the Natural History Museum, London and were extensively used by later coral taxonomists.

\section{THE EARLY 20TH CENTURY}

Except for the Baudin Expedition all the above natural science activities were incidental to the main purpose of the respective voyages. It was not until the early 20th century that marine scientists visited the Kimberley coast with the express purpose of studying marine habitats and biota.

The Swedish Mjöberg Expedition to Australia (1910-1913) included a period working from Broome. Collecting sites were mainly on shores around Broome and the pearling grounds off Cape Jaubert. The results on marine fauna were published over the years 1917-1920 with contributions as follows:
Part XVII, 1917.
N.H.J. Odhner. Mollusca
Part XIX, 1918.
S. Ekmar. Holothuroidea
Part XX, 1918.
K.E. Johannson.
Serpulimorpha, Anneliden
Part XXI, 1918.
T.H. Mortensen. Echinoidea
Part XXII, 1919.
F. Folkenson. Madreporaria
Part XXIII, 1919.
T. Gislen. Crinoids
Part XXIV, 1920.
E. Marcus. Bryozen

In 1916 Herbert Basedow, a geologist from Adelaide, journeyed in the West Kimberley, which included a period aboard the cutter Rita in the Buccaneer Archipelago area (Basedow 1918). Incidental to the geological objectives of the expedition, Basedow made a collection of mollusc shells, which he forwarded to Charles Hedley at the Australian Museum. A taxonomic list of this material, including description of new species, was published in Basedow's narrative (Hedley 1918).

American echinoderm specialist Hubert Lyman Clark spent two months at Broome in 1929 and another month in 1932. His own collecting was supplemented by material obtained from pearling luggers operating in the area between Cape Leveque and Wallal. In this he was assisted by master pearler and amateur conchologist Bernard Bardwell. He also obtained specimens collected at Augustus Island and provided by the Port George Mission. During the 1932 trip he undertook some dredging off the coast between Eighty Mile Beach and Cape Leveque. Clark's specimens are preserved in the collections of the Museum of Comparative Zoology, Harvard University, where the many type specimens may be examined today. His results were included in major publications on the Australian echinoderm fauna (Clark 1938, 1946).

\section{PRIVATE EXPLORATION IN THE KIMBERLEY PROJECT AREA}

In 1923, E.J. Stuart published an account of a visit he made in 1917 to the Kimberley with descriptions of '.. islands and smaller bays interwoven with coral reefs. Some of the latter were very beautiful, as will be seen from the photographs which were taken a little to the west of Dugong Bay.' The remarkable photographs published in Stuart's book are part of a series taken by expedition member William J. Jackson, currently lodged in the National Library with some copies in the Western Australian State Library and negatives in the Western Australian Museum. Jackson also made a cinematic record and parts of that film are preserved (see Robinson 1976a, 1976b; Smith 1996).

In 1934-1935, J.R. Grey FRGS and his wife Beatrice Grey FLS (née Taylor) travelled along the Kimberley coast in their private vessel Silver Gull. Beatrice Grey was a parasitologist and she made collections of marine specimens in the region, which were sent to the then British Museum of Natural History. Correspondence between this author and curatorial staff of the Natural History Museum (London) has revealed that there is an extensive collection of letters from Beatrice Grey in the museum's archives.

\section{THE CONTEMPORARY ERA}

After Clark, there followed a period of 40 years during which little attention was paid to 
Kimberley marine habitats and their biota by researchers, although some collections (mainly molluscan shells) found their way into Australian museum collections. However, there was some oceanographic and marine geological research, especially on the Sahul Shelf, including important studies on coral reefs of the region (Teichert and Fairbridge 1948; Fairbridge 1950, 1953; Carrigy and Fairbridge 1954; Jones 1973; Jongsma 1974). Biological survey work on the North West Shelf and along the Kimberley coast by WAM, the Department of Fisheries Western Australia (DoFWA) and the Commonwealth Scientific Industrial and Research Organisation (CSIRO) began in the 1970s.

It is convenient to consider subsequent biological research under three headings; the coastal bioregions of the Kimberley, studies of benthic and demersal faunas of the shelf, and the reefs of the offshore Oceanic Shoals Bioregion.

\section{THE SHORE BIOTA OF KIMBERLEY COASTAL BIOREGIONS}

\section{Geomorphic and habitat studies}

There is a considerable body of geomorphic information on coastal marine and estuarine habitats of the Kimberley coast. Accounts have been published on the geomorphology and Holocene history of tidal flats in Cambridge Gulf and the estuary of the Ord River (Wright et al. 1972, 1973; Thom et al. 1975; Wolanski et al. 2001) and the Kimberley, King Sound and Canning bioregions (Semeniuk 1980, 1981a, 1981b, 1982, 1985, 2008, 2011; Brocx and Semeniuk 2011; Mathews et al. 2011). Many relevant papers appeared in the proceedings of the recent Symposium on Kimberley Marine and Coastal Science (Brocx and Meney 2011). In the last few years there has been considerable environmental work associated with development of the hydrocarbon resources of the offshore Browse Basin and assessment of Kimberley natural heritage values. Much of this work remains unpublished.

\section{Biological surveys and development of taxonomic knowledge}

The results of the Swedish Mjöberg Expedition (1910-1913) and the studies of Clark (1938, 1946) on echinoderms established a basis of taxonomic knowledge of some coastal marine taxa, primarily for the Canning Bioregion. The biota of the Kimberley and Bonaparte Gulf Bioregions remained virtually unknown until the second half of the 20th century.

A large collection of molluscan shells, mainly from the Canning Bioregion pearling grounds, but including some specimens from the Kimberley and King Sound Bioregions, assembled over the years by amateur conchologist Bernard Bardwell of Broome, was purchased by the National Museum of Victoria in the early 1960s. Virginia Orr of the Philadelphia Academy of Natural Sciences spent several weeks in Broome in the mid 1960s, collecting shore molluscs, again mainly from the Canning Bioregion. Both these collections have been useful sources of research material cited in many subsequent taxonomic studies.

In the last few decades of the 20th century, WAM staff were active in the region, developing extensive collections and sponsoring taxonomic research thereon by specialists around the world, with knowledge of the regional fauna rapidly expanding. That process is ongoing and vigorously pursued, the present series of papers being a collation of both previous work and recent museum surveys in the region.

WAM published a systematic list of marine molluscs from the north Kimberley, based on visits to the Institut Islands, Cape Voltaire and Admiralty Gulf in August and October to November of 1976 (Wells 1981). Wells subsequently collected additional mollusc material during visits to islands of the Kimberley Bioregion in 1988 (Wells 1989, 1990, 1992).

In 1991, WAM began a series of collecting expeditions on the Kimberley coast, sampling a range of plant, invertebrate and fish taxa, mostly from rocky shore and coral reef habitats around the coastal islands. The reports of these expeditions, though unpublished, significantly extended the lists of known species of Kimberley marine fauna and flora (Morgan 1992; Wells et al. 1995; Walker et al. 1996; Walker 1997). The recent Kimberley expeditions to Montgomery Reef and Adele Island in 2009, and Cassini Island and Long Reef in 2010, supported by Woodside Energy, have continued this survey work. There have also been the WAM surveys on marine invertebrates on the sandy coast of the Canning Bioregion (Bryce et al. 1997). Most of the collections made during these surveys are lodged in WAM (fauna) and the Western Australian Herbarium (flora) and the associated data are incorporated in this series of papers.

Another major contribution to knowledge of the North West Shelf coastal invertebrate fauna is an ongoing international study, coordinated by the Royal Netherlands Institute for Sea Research, on the vast mudflats of Roebuck Bay and Eighty Mile Beach in the Canning Bioregion (de Goeij et al. 2003; Honkoop et al. 2006; Piersma et al. 2002, 2005a, 2005b; Compton et al. 2008; Estrella et al. 2011). These studies were designed to provide understanding of the intertidal habitats and food resources of the large numbers of migratory shorebirds utilising these Ramsar Wetland mudflats. 
In 2006-2007, a study of intertidal rocky shore and fringing reef habitats and biota of the Bonaparte Archipelago was carried out for INPEX Browse Ltd as part of an environmental impact assessment relating to a proposed LNG facility on the Maret Islands. The proposal did not proceed, but invertebrate specimens collected during the project have been lodged with WAM. Results of that environmental study have been published by INPEX (Rosser et al. 2014).

\section{THE BENTHIC AND DEMERSAL BIOTA OF THE CONTINENTAL SHELF}

The demersal fish fauna of the continental shelf adjacent to the Kimberley coast is moderately well known as a result of fishery stock surveys by the DoFWA and CSIRO (Sainsbury et al. 1985; Sainsbury 1987; Nowara and Newman 2001; Newman and Dunk 2002; Molony et al. 2011) and studies of fish species distribution and stock variability on the North West Shelf (Hutchins 1999; Travers et al. 2010; Holliday et al. 2011).

Benthic invertebrates of the continental shelf in the region are less well known. The Swedish expedition and Clark's work on echinoderms (see above) included material obtained by dredging on the inner shelf of the Canning Bioregion. Fry et al. (2008) reported the results of a dredging and video survey of nearshore benthic habitats in the Canning Bioregion, including a classification of the habitat types encountered, but at the time of this publication the invertebrates collected have not been identified except for key species that were particularly common.

In December 1969 the Japanese fisheries research ship Umitaka Maru dredged 17 stations at depths from $29 \mathrm{~m}$ and $260 \mathrm{~m}$ between Joseph Bonaparte Gulf and the Rowley Shoals. Molluscan material from these stations was presented to WAM.

In 1962, aboard the fishing vessel Dorothea, R.W. George of WAM dredged a number of stations off the Kimberley coast as far north as Troughton Island at depths from 22-90 m. A few years later, CSIRO conducted a series of scampi resource surveys aboard the vessels Courageous and Soela on the slope of the North West Shelf using Engel trawls. Museum staff participated in several of these surveys and sampled benthic invertebrates at stations in the vicinity of the Rowley Shoals at depths from $276-520 \mathrm{~m}(1979,1982)$ and off the Kimberley coast between Broome and Augustus Island at depths from 200-600 m (1984).

\section{REEF HABITATS AND BIOTA OF THE SHELF EDGE}

Surveys by WAM, the Museum and Art Gallery of the Northern Territory and AIMS have described the habitats and biota of the shelf margin coral reef ecosystems, for some taxa. The biota of the Rowley Shoals, Scott and Seringapatam Reefs have been described in papers edited by Berry (1986) and Bryce (2009) and in reports published by AIMS (Done et al. 1994; Heyward et al. 1997). The biota of Ashmore and Hibernia Reefs and Cartier Island have been described in papers edited by Berry (1993) and Russell et al. (2005) and survey reports by Griffith (1997), Skewes et al. (1999), Kospartov et al. (2006) and Richards et al. (2009). Information on the marine ecology of Browse Island is provided in a publication based on a field survey report by consulting firm RPS (RPS Bowman Bishaw Gorham 2007).

\section{THE CONTEMORARY ERA AND FUTURE DIRECTIONS}

The early pioneering surveys undertaken by WAM and collaborating institutions and the more recent Woodside Collection Project (Kimberley) have established baseline knowledge of the marine flora and fauna and associated habitats of the region. Inevitably, the information acquired so far is patchy, both in terms of the areas and habitats surveyed and the taxonomic groups that have been addressed.

Most attention has been directed to the coral reefs of the shelf margin and the fringing reefs and rocky shores of the Kimberley islands and to some degree the coast, and these habitats are a major focus of this series of papers. While there will always be more that could be done, enough is now known about the composition of the flora and fauna of these areas and habitats for their biogeographic affinities and biodiversity to be assessed and compared. Much less is known of Kimberley benthic shelf habitats and biota. This applies to both the sandy shores, especially in the Canning Bioregion, and soft seafloor substrata of the continental shelf. These habitats are known to be also species rich, but their flora and fauna remain essentially undescribed. The same situation applies to the epifaunal communities inhabiting the rocky substrata of the seafloor of the continental shelf. These filter feeding communities are diverse and widespread in the region, both on the topographically complex inner shelf of the Kimberley coast and on rocky terraces representing old shorelines of the middle shelf.

Taxonomically a similar situation prevails. Intertidal and shallow subtidal plants, fishes, scleractinian corals, echinoderms and larger crustaceans and molluscs are adequately covered for the coral reefs of the shelf region. However, small crustaceans and molluscs $(<5 \mathrm{~mm})$ may be a significant component of benthic ecosystems that are poorly known; so too are all the community assemblages of the coastal habitats and benthic 
filter feeding communities. Whilst there is a large volume of literature on fossil Foraminifera, which are important in studies of stratigraphy in the region, little is known of the living pelagic and benthic species of this diverse group and the role they play in contemporary ecology and sedimentation processes. The Kimberley marine minor phyla, including the platyhelminthes, nemertines, brachiopods and bryozoans are virtually unstudied. It is natural that the major taxa should receive most taxonomic attention as they are the most easily collected and studied and generally play significant roles in forming the structure of communities and in reef building processes (especially plants and corals). However, when it comes to ecological studies, taxonomic attention will be needed to address some of the smaller creatures for these generally form the bases of trophic systems and secondary production.

One of the principles of environmental protection and management is 'the conservation of biological diversity and ecological integrity' (Environmental Protection Authority, 2004.) A goal of faunistic and taxonomic studies is to provide a framework and knowledge base that may support this principle. This series of Kimberley papers marks an essential 'first step' towards meeting these goals, but there remains much to be done. Species lists and taxonomic arrangements are but the beginning. Biodiversity conservation and management practice need an understanding also of functional groups, especially in regard to key species assemblages, trophic pathways and community building processes (McClanahan et al. 2002; Bellwood et al. 2004; Marshall and Schuttenberg 2006). Further work is needed to fill in the information gaps relating to poorly studied habitats and taxa and to consideration of ecological assemblages and functional groups.

\section{REFERENCES}

Baker, C., Potter, A., Tran, M. and Heap, A.D. (2008). Sedimentology and geomorphology of the North-west Marine Region of Australia. Geoscience Australia Record 2008/07: Canberra.

Basedow, H. (1918). Narrative of an expedition of exploration in north-western Australia. Proceedings of the Royal Geographical Society of Australasia, South Australian Branch 18: 105-295.

Bassett-Smith, P.W. (1899). On the formation of the coralreefs on the N.W. coast of Australia. Proceedings of the Zoological Society of London 1899: 157-159.

Beard, J.S. (1967). Some vegetation types of tropical Australia in relation to those of Africa and America. Journal of Ecology 55: 271-290.

Bellwood, D.R., Hughes, T.P., Folke, C. and Nystrom, M. (2004). Confronting the coral reef crisis. Nature 429: 827-833.

Berry, P.F. (ed.) (1986). Faunal surveys of the Rowley Shoals, Scott Reef and Seringapatam Reef. Records of the Western Australian Museum Supplement 25.
Berry, P.F. (ed.) (1993). Marine faunal surveys of Ashmore Reef and Cartier Island, North-Western Australia. Records of the Western Australian Museum Supplement 44.

Brocx, M. and Meney, K. (eds) (2011). Symposium on Kimberley marine and coastal science. Journal of the Royal Society of Western Australia 94(2): 55-418.

Brocx, M. and Semeniuk, V. (2011). The global geoheritage significance of the Kimberley coast. Journal of the Royal Society of Western Australia 94(2): 57-88.

Bryce, C. (ed.) (2009). Marine biodiversity survey of Mermaid (Rowley Shoals), Scott and Seringapatam Reefs. Records of the Western Australian Museum Supplement 77.

Bryce, C.W., Hutchins, J.B. and Fromont, J. (1997). Restricted marine biological survey of the 'garden bottom' of Beagle Bay, Kimberley, Western Australia. Western Australian Museum: Perth. Unpublished report.

Carrigy, M.A. and Fairbridge, R.W. (1954). Recent sedimentation, physiography and structure of the continental shelves of Western Australia. Journal of the Royal Society of Western Australia 37: 65-95.

Clark, H.L. (1938). Echinoderms from Australia. Memoirs of the Museum of Comparative Zoology, Harvard 55: 1-595.

Clark, H.L. (1946). The echinoderm fauna of Australia. Publications of the Carnegie Institution 566: 1-567.

Collins, L.B., Testa, V., Zhao, J. and Qu, D. (2011). Holocene growth history and evolution of the Scott Reef carbonate platform and coral reef. Journal of the Royal Society of Western Australia 94(2): 239-250.

Commonwealth of Australia (2006). A guide to the integrated marine and coastal regionalisation of Australia, Version 4.0. Department of the Environment and Heritage, Canberra.

Compton, T.J., Troost, T.A., Van der Meere, J., Krann, C., Honkoop, P.J., Rogers, D., Pearson, G.B., de Goeij, P., Bocher, P., Lavaleye, M.S.S., Leyrer, J., Yates, M.G., Dekinga, A. and Piersma, T. (2008). Distributional overlap rather than habitat differentiation characterises co-occurrence of bivalves in intertidal soft sediment systems. Marine Ecology Progress Series 373: 25-35.

Cornell, C. (translator) (1974). The Journal of Post Captain Nicholas Baudin. Libraries Board of South Australia: Adelaide.

Cresswell, I.D. and Semeniuk, V. (2011). Mangroves of the Kimberley region: ecological patterns in a tropical ria coast setting. Journal of the Royal Society of Western Australia 94(2): 213-237.

D'Adamo, N., Fandry, C., Buchan, S. and Domingues, C. (2009). Northern sources of the Leeuwin Current and the 'Holloway Current' on the North West Shelf. Journal of the Royal Society of Western Australia 92: 53-66.

Dana, J.D. (1853). On coral reefs and islands. Putnam: New York.

Darwin, C. (1842). The structure and distribution of coral reefs. Smith Elder \& Co.: London.

Done, T.J., Williams, D. McB., Speare, P.J., Turak, E., Davidson, J., DeVantier, L.M., Newman, S.J. and Hutchins, J.B. (1994). Surveys of coral and fish communities at Scott Reef and Rowley Shoals. Australian Institute of Marine Science: Townsville.

Elliott, R.M.L. (1990). Browse Basin (pp. 535-561). In: Geology and mineral resources of Western Australia. Memoir 3, Geological Survey of Western Australia: Perth.

Environmental Protection Authority (2004). Principles of environmental protection, Position Statement No. 7, Western Australian Environmental Protection Authority: Perth. 
Estrella, S.M., Storey, A.W., Pearson, G. and Piersma, T. (2011). Potential effects of Lyngbya majuscula blooms on benthic invertebrate diversity and shore-bird foraging ecology of Roebuck Bay. Journal of the Royal Society of Western Australia 94(2): 171-179.

Fairbridge, R.W. (1950). Recent and Pleistocene coral reefs of Australia. Journal of Geology 58(4): 330-401.

Fairbridge, R.W. (1953). The Sahul Shelf, northern Australia: its structure and geological relationships. Journal Royal Society of Western Australia 37: 1-34.

Fry, G., Heyward, A., Wassenberg, T., Colquhoun, J., Pitcher, R., Smith, G., Ellis, N., Stieglitz, T., Taranto, T., Keesing, J., Irvine, T., Pendrey, R., Cheers, S., Cook, K., Thomson, D., Vanderklift, M., Brewer, D., Brookes, K., Cannard, T., Chetwynd, A., Hunt, O., McLeod, I., Speare, P., Van der Welde, T., Woodley, S. (2008). Benthic habitat surveys of potential LNG hub locations in the Kimberley region. A joint Commonwealth Scientific and Industrial Research Organisation and Australian Institute of Marine Sciences report for the Western Australian Marine Science Institution.

Glenn, K. (2004). Sedimentary processes during the Late Quaternary across the Kimberley Shelf, northwest Australia. Thesis, University of Adelaide: Adelaide.

Glenn, K. (2005). Water properties of Ashmore Reef. In: Russell, B.C., Larson, C.J., Glasby, R.C., Willan, R.C. and Martin, J. (eds). Understanding the cultural and natural heritage values and management challenges of the Ashmore Region. Records of the Museums and Art Galleries of the Northern Territory Supplement 1: 9-12.

Goeij, P., Lavaleye, M., Pearson, G.B. and Piersma, T. (2003). Seasonal changes in the macro-zoobenthos of a tropical mudflat. Report 2003/4. Netherlands Institute for Sea Research, Texel: Netherlands.

Gray, J.E. (1827a). In: King, P.P. Narrative of a survey of the intertropical and western coasts of Australia, performed between the years 1818 and 1822, John Murray: London, Volume. 2: 412-414.

Gray, J.E. (1827b). In: King, P.P. Narrative of a survey of the intertropical and western coasts of Australia, performed between the years 1818 and 1822, John Murray: London, Volume 2: 435-437.

Gray, J.E. (1827c). Mollusca. In: King, P.P. Narrative of a survey of the intertropical and western coasts of Australia, performed between the years 1818 and 1822, John Murray: London, Volume 2: 474-496.

Griffin, T.J. and Grey, K. (1990a), King Leopold and Halls Creek Orogens (pp. 232-255). In: Geology and Mineral Resources of Western Australia. Memoir 3, Western Australia Geological Survey: Perth.

Griffin, T.J. and Grey, K. (1990b). Kimberley Basin (pp. 293-304). In: Geology and Mineral Resources of Western Australia. Memoir 3, Geological Survey of Western Australia: Perth.

Griffith, J.K. (1997). The corals collected during September/ October 1997 at Ashmore Reef, Timor Sea. Report to the Department of the Environment, Water, Heritage and the Arts. Unpublished report.

Gunn, P.J. (1988). Bonaparte Basin: evolution and structural framework (pp. 275-285). In: Purcell. P.G. and Purcell, R.R. Geology and Mineral Resources of Western Australia. Memoir 3, Geological Survey of Western Australia: Perth.

Hedley, C. (1918). Narrative of an expedition of exploration in North Western Australia by Herbert Basedow. Special Report. Mollusca. Transactions of the Royal
Geogeographical Society of Australia. South Australian Branch 18: 263-283.

Heyward, A., Pinceratto, E. and Smith, L. (eds) (1997). Big Bank Shoals of the Timor Sea: An Environmental Resource Atlas. Australian Institute of Marine Science: Townsville.

Holliday, D., Beckley, L.E., Weller, E. and Sutton, A.L. (2011). Natural variability of macro-plankton and larval fishes off the Kimberley, north-western Australia: Preliminary findings. Journal of the Royal Society of Western Australia 94(2): 181-194.

Honkoop, P.J.C., Pearson, G.B., Lavaleye, M.S.S. and Piersma, T. (2006). Spatial variation of the intertidal sediments and macrozoo-benthic assemblages along Eighty-Mile Beach, north-western Australia. Journal of Sea Research 55: 278-291.

Horstman, E.L. and Purcell, P.G. (1988). The offshore Canning Basin - A Review. In: Purcell, P.G. and Purcell, R.R. (eds) The North West Shelf Australia, Proceedings of the Petroleum Exploration Society, Australia Symposium, Perth, 1988, 253-257.

Hutchins, J.B. (1999). Biogeography of the nearshore marine fish fauna of the Kimberley, Western Australia. In: Séret, B. and Sire, J-Y. (eds), Proceedings of the Fifth Indo-Pacific Fish Conference, Noumea 1997: 99-108.

James, N.P. Bone, Y., Kyser, T.K., Dix, G.R. and Collins, L.B. 2004. The importance of changing oceanography in controlling late Quaternary carbonate sedimentation on a high-energy, tropical, oceanic ramp: north-western Australia. Sedimentology 51(6): 1179-1205.

Jennings, J.N. (1975). Desert dunes and estuarine fill in the Fitzroy estuary, North-Western Australia. Catena 2: 215-262.

Jones, H.A. (1973). Marine Geology of the Northwest Australian Continental Shelf. Bureau of Mineral Resources, Geology and Geophysics Bulletin 136: 1-102.

Jongsma, D. (1974). Marine geology of the Arafura Sea. Bureau of Mineral Resources, Geology and Geophysics Bulletin 157: 1-73, plates 1-6, map.

Jutson, J.T. (1934). The physiography (geomorphology) of Western Australia. Bulletin of the Geological Survey of Western Australia 61.

King, P.P. (1827a). Narrative of a survey of the intertropical and western coasts of Australia, performed between the years 1818 and 1822. 2 volumes. John Murray: London. Volume 2: 410.

King, P.P. (1827b). Narrative of a survey of the intertropical and western coasts of Australia, performed between the years 1818 and 1822. 2 Volumes. John Murray: London. Page 56, entry for July 30, 1821.

Kospartov, M., Beger, M., Ceccarelli, D. and Richards, Z. (2006). An assessment of the distribution and abundance of sea cucumbers, trochus, giant clams, coral, fish and invasive marine species at Ashmore Reef National Nature Reserve and Cartier Island Marine Reserve. UniQuest report to the Department of Environment and Heritage: Canberra. Unpublished report.

Lavering, I.H. (1993). Quaternary and modern environments of the Van Dieman Rise, Timor Sea and potential effects of additional petroleum exploration activity. BMR Journal of Australian Geology and Geophysics 13(4): 281-292.

Marsh, L.M. and Marshall, J. (1983). Some aspects of the zoogeography of northwestern Australian echinoderms (other than holothurians). Bulletin of Marine Science 33(3): 671-87. 
Marshall, P.A. and Schuttenberg, H.Z. (2006). A reef manager's guide to coral bleaching. Great Barrier Reef Marine Park Authority: Townsville.

Mathews, D., Semeniuk, V and Semeniuk, C. (2011). Freshwater seepage along the coast of the western Dampier Peninsula, Kimberley region, Western Australia. Journal of the Royal Society of Western Australia 94(2): 207-212.

McClanahan, T.R., Polunin, N.V.C. and T.J. Done. (2002). Resilience of coral reefs. In: L. Gunderson, B.-O. Jansson, C.S. Hollings and C. Folke (eds), Resilience and the behavior of large-scale ecosystems. Island Press, Washington, DC: 111-163.

McKenzie, N.L. (1991). An ecological survey of tropical rainforests in Western Australia: background and methods. In: McKenzie, N.L., Johnston, R.B. and Kendrick, P.G. (eds), Kimberley rainforests of Australia, Surrey Beatty \& Sons: Chipping Norton, Australia.

Middleton, M.F. (1990). Canning Basin (pp. 425-453). In: Geology and Mineral Resources of Western Australia. Memoir 3, Geological Survey of Western Australia: Perth.

Molony, B.W., Newman, S.J., Joll, L. and Lenanton, R.C.J. (2011). Are Western Australian waters the least productive waters for finfish across two oceans? Journal of the Royal Society of Western Australia 94(2): 323-332.

Morgan, G. J. (1992) (ed.) Survey of the Aquatic Fauna of the Kimberley Islands and Reefs, Western Australia. Report of the Western Australian Museum Kimberley Island and Reefs Expedition, August 1991. Western Australian Museum: Perth. Unpublished report.

Mory, A.J. (1990). Bonaparte Basin (pp. 380-415). In: Geology and Mineral Resources of Western Australia. Memoir 3, Geological Survey of Western Australia: Perth

Newman, S.J. and Dunk, I.J. (2002). Growth, age validation, mortality, and other population characteristics of the red emperor snapper, Lutjanus sebae (Cuvier, 1828) off the Kimberley coast of north-western Australia. Estuarine, Coastal and Shelf Science 55: 67-80.

Nowara, G.B. and Newman, S.J. (2001). A history of foreign fishing activities and fishery-independent surveys of the demersal finfish resources in the Kimberley region of Western Australia. Fisheries Research Report No. 125: 1-84.

O'Brien, G.W. and Woods, E.P. 1995. Hydrocarbonrelated diagenetic zones (HRDZs) in the Vulcan Sub-basin, Timor Sea: recognition and exploration implications. Australian Petroleum Production and Exploration Association Journal 35: 220-252.

O'Brien, G.W. and Glenn, K.C. 2005. Natural hydrocarbon seepage, sub-seafloor geology and eustatic sea-level variations as key determiners of the nature and distribution of carbonate build-ups and other benthic habitats in the Timor Sea (pp. 31-42). In: Russell, B.C., Larson, C.J., Glasby, R.C., Willan, R.C. and Martin, J. (eds). Understanding the Cultural and Natural Heritage Values and Management Challenges of the Ashmore Region. Records of the Museums and Art Galleries of the Northern Territory Supplement 1.

Piersma, T., Pearson, G., Hickey, B., Lavaleye, M. and Rogers, D. (2002). Preliminary Research Report. Southern Roebuck Bay Invertebrate and Bird Mapping 2002. Broome Bird Observatory. Unpublished report.

Piersma, T., Pearson, G.B., Hickey, R. and Lavaleye, M. (eds) (2005a). The long mud: benthos and shorebirds of the foreshore of Eighty-Mile Beach, Western Australia. Royal Netherlands Institute for Sea Research, Texel, Netherlands, Report 2005/2.
Piersma, T., Rogers, D.I. , Gonzalez, P.M., Zwarts, L., Niles, L. J., de Lima S. do Nascimento, I. , Minton, C.D.T. and Baker, A.J. (2005b). Fuel storage rates before northward flights in red knots worldwide: facing the severest ecological constraint in tropical intertidal environments? In: Greenberg, R. and Marra, P.P. (eds), Birds of two worlds: ecology and evolution of migration. Johns Hopkins University Press: Baltimore. 262-273.

Przeslawski, R., Daniell, J., Anderson, T., Vaughn Barrie, J., Battershill, C., Heap, A., Hughes, M., Li, J., Potter, A., Radke, L., Siwabessy, J., Tran, M., Whiteway, T., Nichol, S. (2011). Seabed habitats and hazards of the Joseph Bonaparte Gulf and Timor Sea, Northern Australia. Geoscience Australia Record 2011/40, Australian Government: Canberra.

Richards, Z., Beger, M., Hobbs, J-P., Bowling, T., ChongSeng, K. and Pratchett, M. (2009). Ashmore Reef National Nature Reserve. Marine Survey 2009. Report to the Department of the Environment, Water, Heritage and the Arts: Canberra. Unpublished report.

Robinson, M.V. (1976a).The Jackson Film of 1917. Australian Institute of Aboriginal Studies Newsletter. June 1917: 17-20.

Robinson (1976b). The Film That Vanished ... the Jackson Film of 1917. Department of Aboriginal Affairs Newsletter 2(6): 10-19.

Rosser, N., Wilson, B., Forde, M., Fitzpatrick, J., Scoones, R., and Huismann, J. (2014). Marine ecology. In: Comrie-Greig, J. and Abdo, L.J. (eds), Ecological studies of the Bonaparte Archipelago and Browse Basin. INPEX Operations Australia Pty Ltd: Perth.

RPS Bowman Bishaw Gorham. (2007). Inpex environmental impact assessment studies, technical appendix - marine intertidal. Unpublished report.

Russell, B.C., Larson, C.J., Glasby, R.C., Willan, R.C. and Martin, J. (eds) (2005). Understanding the cultural and natural heritage values and management challenges of the Ashmore region. Records of the Museums and Art Galleries of the Northern Territory Supplement 1.

Sainsbury, K.J. (1987). Assessment and management of the demersal fishery on the continental shelf of north western Australia (pp. 465-503). In: Polovina, J.J. and Ralston, S. (eds), Tropical Snappers and Groupers, Biology and Fisheries Management.

Sainsbury, K.J., Kailola, P.J. and Leyland, G.G. (1985). Continental shelf fishes of northern and north western Australia. An illustrated guide. John Wiley and Sons: London.

Semeniuk, V. (1980). Quaternary stratigraphy of the tidal flats, King Sound, Western Australia. Journal Royal Society of Western Australia 63(3): 65-78.

Semeniuk, V. (1981a). Long-term erosion of the tidal flats, King Sound, North-Western Australia. Marine Geology 43: 21-48.

Semeniuk, V. (1981b). Sedimentology and the stratigraphic sequence of a tropical tidal flat, North-Western Australia. Sedimentary Geology 29: 195-221.

Semeniuk, V. (1982). Geomorphology and the Holocene history of the tidal flats, King Sound, north-western Australia. Journal Royal Society of Western Australia 65(2): 47-68.

Semeniuk, V. (1985). Development of mangrove habitats along ria shorelines in north and north-western tropical Australia. Vegetatio 60: 3-23.

Semeniuk, V. (1993). The mangrove systems of Western Australia: 1993 Presidential Address. Journal of the Royal Society of Western Australia 76: 99-122. 
Semeniuk, V. (2008). Holocene sedimentation, stratigraphy, biostratigraphy, and history of the Canning Coast, north-western Australia. Journal of the Royal Society of Western Australia 91(1): 53-148.

Semeniuk, V. (2011). Stratigraphic patterns in coastal sediment sequences in the Kimberley region: products of coastal form, oceanographic setting, sedimentary suites, sediment supply, and biogenesis. Journal of the Royal Society of Western Australia 94(2): 133-150.

Skewes, T.D., Gordon, S.R., McLeod, I.R., Taranto, T.J., Dennis, D.M., Jacobs, D.R., Pitcher, C.R. Hatwood, M., Smith, G.P., Poiner, I.R., Milton, D., Griffin, D. and Hunter, C. (1999). Survey and Stock Size Estimates of the Shallow Reef (0-15 $m$ deep) and Shoal Area (15-50 m deep) Marine Resources and Habitat Mapping within the Timor Sea MOU74 Box. Vol. 2: Habitat Mapping and Coral Dieback. CSIRO Report, 1-59. Unpublished report.

Slayter, R.O. (1960). Climate of the North Kimberley. In: Speck, N.H. et al. The land and pastoral resources of the North Kimberley area, W.A. Land Resource Series C.S.I.R.O. Australia, No. 4: 1-109.

Smith, M. (1996). Jackson's film of the North West Scientific Expedition. Bulletin of the Conference of Australian Anthropologists No. 29: 30-38.

Stokes, J.L. (1846). Discoveries in Australia; with an account of the coasts and rivers explored and surveyed during the voyage of H.M.S. Beagle, in the years 18371843 by command of the Lords Commissioners of the Admiralty, also a narrative of Captain Owen Stanley's visits to the islands in the Arafura Sea, 2 volumes. T. and W. Boone: London.

Stuart, E.J. (1923). A Land of opportunities, being an account of the author's recent expedition to explore the northern territories of Australia. John Lane Bodley Head Ltd.: London.

Teichert, C. and Fairbridge, R.W. (1948). Some coral reefs of the Sahul shelf. Geographical Review 38(2): 222-249.

Thom, B.G., Wright, L.D. and Coleman, J.M. (1975). Mangrove ecology and deltaic-estuarine geomorphology; Cambridge Gulf-Ord River, Western Australia. Journal of Ecology, 63: 203-232.

Travers, M.J., Potter, I.C., Clarke, K.R., Newman, S.J. and Hutchins, J.B. (2010). The inshore fish faunas over soft substrates and reefs on the tropical west coast of Australia differ and change with latitude and bioregion. Journal of Biogeography. 37: 148-169.

Tyler, I.M, Hocking, R.M, Haines, P.W. (2012). Geological evolution of the Kimberley region of Western Australia. Episodes 35: 298-306.

Walker, D.I., Wells, F.E. and Hanley J.R. (1996) (eds). Marine biological survey of the eastern Kimberley, Western Australia. University of Western Australia, Western Australian Museum and Museum and Art Gallery of the Northern Territory. Unpublished report.

Walker, D.I. (1997) (ed.). Marine biological survey of the central Kimberley coast, Western Australia. University of Western Australia: Perth. Unpublished report.

Wells, F.E. (1981). Molluscan fauna of the Admiralty Gulf, Cape Voltaire, and the Institut Islands, Kimberley, Western Australia. Chitons, Meso and Neogastropods. In: Wilson, B.R. (ed.), Biological survey of Mitchell Plateau and Admiralty Gulf, Kimberley, Western Australia. Western Australian Museum: Perth. Part 8: 249-263.

Wells, F.E. (ed.) (1989). Survey of the invertebrate fauna of the Kimberley islands, Western Australia. A report to the National Geographic Society. Western Australian Museum: Perth. Unpublished report.
Wells, F.E. (1990). Comparative zoogeography of marine molluscs from northern Australia, New Guinea and Indonesia. Veliger 33: 140-144.

Wells, F.E. (1992). Molluscs Part IV (pp. 30-42). In: Morgan, G.J. (ed.) Survey of the aquatic fauna of the Kimberley islands and reefs, Western Australia. Report of the Western Australian Museum Kimberley island and reefs expedition, August 1991. Western Australian Museum: Perth. Unpublished report.

Wells, F.E., Hanley, J.R. and Walker, D.I. (1995) (eds). Marine biological survey of the southern Kimberley, Western Australia. Western Australian Museum: Perth. Unpublished report.

Wells, F.E. and Allen, G.R. 2005. Marine biodiversity on offshore reefs in north-western Australia (pp. 43-50). In: Russell, B.C., Larson, C.J., Glasby, R.C., Willan, R.C. and Martin, J. (eds), Understanding the cultural and natural heritage values and management challenges of the Ashmore region. Records of the Museums and Art Galleries of the Northern Territory Supplement 1: Darwin.

Williams, I.R. and Sofoulis, J. (1971). Explanatory notes on the Prince Regent and Camden Sound Geological Sheets. Bureau of Mineral Resources, Geology and Geophysics, Commonwealth of Australia: Canberra.

Willis, I. (1988). Results of Exploration, Browse Basin, North West Shelf, Western Australia (pp. 259-272). In: Purcell, P.G. and Purcell, R.R. (eds), The North West Shelf of Australia. Petroleum Exploration Society of Australia: Perth.

Wilson, B.R. and Gillett, K. (1971). Australian shells. Read: Sydney.

Wilson, B.R. and Allen, G.R. (1987). Major components and distribution of marine fauna (pp. 43-68). In: Dyne, G.R. and Walton, D.W. (eds), Fauna of Australia, Australian Government Publishing Service: Canberra.

Wilson, B.R. and Blake, S. (2011). Notes on the origins and biogeomorpholgy of Montgomery Reef, Kimberley, Western Australia. Journal of the Royal Society of Western Australia 94: 107-119.

Wilson, B.R. (1985). Notes on a brief visit to Seringapatam Atoll, North West Shelf, Australia. Atoll Research Bulletin 292: 83-100.

Wilson, B.R. (2013). The biogeography of the Australian North West Shelf, Elsevier: Waltham, U.S.A.

Wolanski, E., Moore, K, Spagnol, D'Adamo, N. and Pattiaratchi, C. (2001). Rapid, human-induced siltation of the macro-tidal Ord River Estuary, Western Australia. Estuarine, Coastal and Shelf Science 53(5): 717-732.

Wright, R.L. (1964). Geomorphology of the West Kimberley area. CSIRO Land Research, Series 9: 103-118.

Wright, L.D., Coleman, J.M. and Thom, B.G. (1972). Emerged tidal flats in the Ord River Estuary, Western Australia. Search 3: 339-341.

Wright, L.D., Coleman, J.M. and Thom, B.G. (1973). Processes of channel development in a high tiderange environment: Cambridge Gulf-Ord River delta, Western Australia. Journal of Geology 81: 15-41.

Yokoyama, Y., Lambeck, K., De Decker, P., Johnson, P. and Fifield, L.K. (2000). Timing of the Last Glacial Maximum from observed sea-level minima. Nature 406: 713-716.

Young, R.W. (1992). Structure heritage and planation in the evolution of land forms of the East Kimberley. Australian Journal of Earth Sciences 9: 141-151.

MANUSCRIPT RECEIVED 10 NOVEMBER 2013; ACCEPTED 28 MAY 2014. 